\title{
Suppressor Cell-Mediated Neutropenia in
}

\section{Felty's Syndrome}

\author{
Nabih I. Abdou, Chaiyakiati NaPombejara, Larky Balentine, and \\ NANCY L. ABDOU, The Department of Medicine, Division of Allergy, Clinical \\ Immunology and Rheumatology, University of Kansas Medical Center and \\ Veterans Administration Hospital, Kansas City, Kansas 66103 and Missouri 64128, \\ and Department of Medicine, Division of Oncology-Hematology, University of \\ Missouri, School of Medicine, Kansas City, Missouri 64108
}

A B S TRACT The mechanism of neutropenia in Felty's Syndrome (FS) was tested. The suppressor capacity of mononuclear cells from patients with FS on nqormal bone marrow granulopoiesis was tested by the in vitro colony forming unit in culture assay. Peripheral blood, bone marrow, and spleen cells from FS patients with marked neutropenia $(<1,000$ neutrophils $/ \mathrm{mm}^{3}$ ) suppressed the colony forming unit in culture of normal bone marrow. Cells from rheumatoid arthritis patients without neutropenia, cells from patients with drug-induced neutropenia without rheumatoid arthritis, or plasma from FS patients failed to suppress the colony forming unit in culture. Though suppressor cells were predominantly thymusderived ( $\mathrm{T}$ ) cells, monocytes were also effective in suppression. The suppressor efficiency of cells from the various compartments were spleen $>$ bone marrow $>$ peripheral blood. Splenectomy in FS transiently corrected the neutropenia and eliminated suppressor cell activity.

Hyperactive suppressor cells may be responsible for the neutropenia in some patients with FS. Correction of neutropenia in these patients should be directed at modulating the suppressor cell subpopulation.

\section{INTRODUCTION}

Since Felty first described the triad of rheumatoid arthritis (RA) ${ }^{1}$, splenomegaly, and leukopenia in 1924

This work was presented in part at the International Congress of Rheumatology, 28 June 1977, San Francisco, Calif. Address reprint requests to Dr. N. I. Abdou, University of Kansas Medical Center-416C Kansas City, Kan. 66103.

Received for publication 9 June 1977 and in revised form 14 November 1977.

${ }^{1}$ Abbreviations used in this paper: CFU-C, colony-forming unit assay in culture; FS, Felty's Syndrome; RA, rheumatoid arthritis.
(1), numerous hypotheses have been advanced to explain the pathogenesis of leukopenia. These have included increased splenic sequestration (2), excessive margination of leukocytes with concomitant increased peripheral destruction (3), leukocyte-specific antibodies present in serum (4), and neutrophilbound IgG (5). Defective myelopoiesis has also been found in Felty's Syndrome (FS) and thought to be due to a maturation arrest of the granulocytic series (6) secondary to inhibitory serum factors (7) or lack of myelopoiesis stimulating factors (8).

Thymus-dependent ( $\mathrm{T}$ ) lymphocytes represent a heterogeneous group of cells that have various functions (9). Subpopulations of $\mathrm{T}$ cells, called regulator or suppressor cells, have been shown to inhibit various immune parameters (10). Hyperactive suppressor cells have been implicated in the pathogenesis of the decreased immunoglobulin (Ig) synthesis in some patients with common variable hypogammaglobulinemia (11), the decreased levels of nonparaprotein Ig in multiple myeloma (12), the failure of hematopoiesis in some patients with idiopathic aplastic anemia (13), the decreased erythropoiesis in Diamond-Blackfan Syndrome (14), and in the anergyaccompanying systemic fungal infections (15). On the other hand, defective suppressor cell function has been shown by us to be present and possibly responsible for the emergence of autoreactive clones in active systemic lupus erythematosus (16). There are no published reports on the role of suppressor cells in defective myelopoiesis.

The possibility of lymphocyte-mediated suppression of myelopoiesis has prompted us to examine the neutropenia of FS for the possible role of suppressor cells at the level of the myeloid precursor cell. In this report we have used the granulocyte colonyforming unit assay in culture (CFU-C) and demonstrated the presence of mononuclear suppressor cells 
in spleen, bone marrow, and to a lesser extent, in the blood of patients with FS who have marked neutropenia.

\section{METHODS}

Patient material. Six patients with FS were studied. The clinical and laboratory data are shown in Table I. One patient had splenectomy $4 \mathrm{yr}$ before the study and a second patient was studied presplenectomy and 3 wk and 21 wk postsplenectomy. Four patients had inactive arthritis and three were on no drugs. Two of the patients had received blood transfusions in the past and two of the three females in the study had two normal pregnancies each. Three patients had neutropenia $<1,000 / \mathrm{mm}^{3}$ at the time of the study. All patients had normal monocyte and platelet counts, slight anemia (hemoglobin $10.5-13.2 \mathrm{~g} / 100 \mathrm{ml}$ ), normal serum complement $\left(\mathrm{CH}_{50}\right.$ and $\left.\mathrm{C}_{3}\right)$ and positive antinuclear antibodies (titer 1:40-1:640). Controls for the FS patients were six patients with RA without neutropenia or splenomegaly who were age and sex matched to the FS patients, and three patients with solid tumors under chemotherapy who had neutropenia without RA or splenomegaly. Another group of controls was 10 normal healthy volunteers different from the "normal" bone marrow donors.

Consent forms were obtained from all patients and the study was approved by the Institution Human Experimentation Committee.

Evaluation of suppressor cells. Peripheral blood or bone marrow mononuclear cells were prepared by using the Ficoll-Hypaque technique (16) and from these were prepared enriched T, bone-marrow derived (B), and monocyte-depleted populations (16-18). Enriched T cells were obtained by passage of mononuclear cells through Ig-anti-Ig glass bead columns (18). This yielded cell suspensions containing more than $90 \%$ T cells as tested by the E-rosette method (18). Enriched B cells were obtained by the E-rosette centrifugation method (16). This yielded suspensions containing more than $83 \%$ B cells as tested by staining the cells with fluorescinated anti-Ig (18). Monocytes were depleted by incubating cells with iron filings (Dow Chemical Co., Midland, Mich.) at $37^{\circ} \mathrm{C}$ for $30 \mathrm{~min}$ followed by passage of cells through a polyethylene tube wrapped around a magnet. This yielded $<2 \%$ monocyte contamination as tested by the nonspecific esterase stain (18). Splenic cell suspensions were prepared by mincing splenic fragments gently and forcing cells through a wire mesh as described by us for other organs (17).

The CFU-C assay was performed by plating $2.5 \times 10^{5}$ bone marrow cells per tissue culture plate (Falcon Plastics no. 3002 , Oxnard, Calif.). The cells were mixed in $0.5 \mathrm{ml}$ of $0.6 \%$ agar (Bacto agar, Difco Laboratories, Detroit, Mich.), $0.1 \mathrm{ml}$ fetal calf serum (Flow Laboratories, Inc., Rockville, Md.), and $0.4 \mathrm{ml}$ alpha medium (Flow Laboratories, Inc.). No colonystimulating factors were used in these experiments. The plates were prepared in triplicate and incubated at $37^{\circ} \mathrm{C}$ in a humid atmosphere of $5 \% \mathrm{CO}_{2}$ in air. Colonies with greater than 50 cells were counted by the inverted microscope. Cell aggregates of less than 50 cells were counted as clusters. Since the latter varied to a considerable degree between different experiments from the same donor, we did not record them in the Results section. Cultures from the FS patients were studied at least twice and the mean number of CFU-C from triplicate culture plates were obtained.

TABLE I

Clinical and Laboratory Data

\begin{tabular}{|c|c|c|c|c|c|c|}
\hline Patient: Age $(y r)$ and sex & JC $85 \mathrm{M}$ & $\mathrm{EL} 44 \mathrm{~F}$ & WM $57 \mathrm{M}$ & BB $52 \mathrm{~F}$ & HO $71 \mathrm{M}$ & BP $66 \mathrm{~F}$ \\
\hline \multicolumn{7}{|l|}{ Rheumatoid arthritis } \\
\hline Duration, $y r$ & 35 & 9 & 20 & 10 & 6 & 20 \\
\hline Activity & - & + & + & - & - & - \\
\hline Stage & III & III & III & II & II & III \\
\hline Class & III & III & II & II & III & II \\
\hline Splenomegaly & + & + & + & $\begin{array}{l}\text { Splenectomy } \\
1972\end{array}$ & + by scan & + \\
\hline History of infections & + & - & - & - & + & - \\
\hline \multicolumn{7}{|l|}{ Bone marrow } \\
\hline Cellularity & Hypo & Normo & Normo & Normo & Normo & Hypo \\
\hline $\mathrm{M}: \mathrm{E}$ ratio & $3: 1$ & $1: 3$ & $5: 1$ & $3: 1$ & $2: 1$ & $3: 1$ \\
\hline \multicolumn{7}{|l|}{ Leukocyte count } \\
\hline Total, $\mathrm{mm}^{3}$ & 600 & 3,100 & 3,500 & 1,200 & 2,400 & 1,600 \\
\hline Segmented, \% & 2 & 62 & 78 & 38 & 45 & 13 \\
\hline Bands, \% & 8 & 1 & 10 & 0 & 2 & 5 \\
\hline Sedimentation rate & 100 & 83 & 10 & 30 & 30 & 37 \\
\hline Rheumatoid factor & $1: 5,120$ & $1: 10,240$ & $1: 640$ & $1: 160$ & $1: 80$ & $1: 1,280$ \\
\hline Treatment & $\begin{array}{l}\text { Androgens } \\
\text { Steroids } \\
\text { Splenectomy }\end{array}$ & None & Prednisone & Splenectomy & None & None \\
\hline
\end{tabular}


In all the experiments, "normal" bone marrow was used and consisted of aspirates from patients who had no neutropenia, autoimmune disease, or malignancy. The effect of coculturing $2.5 \times 10^{5}$ allogeneic normal or $2.5 \times 10^{5} \mathrm{FS}$ mononuclear cells or $0.1 \mathrm{ml}$ plasma with $2.5 \times 10^{5}$ normal bone marrow was tested. The percentage of CFU-C formed was expressed by the following formula: \% CFU-C $=(2.5$ $\times 10^{5}$ bone marrow $+2.5 \times 10^{5}$ patient's cells $/ 2.5 \times 10^{5}$ bone marrow $+2.5 \times 10^{5}$ normal's cells) $\times 100$. The percentage of suppression of CFU-C was calculated by the formula: $100-\%$ CFU-C. The CFU-C capacity of FS or normal mononuclear cells was also tested in the absence of the allogeneic normal bone marrow.

We performed several experiments to determine the optimal number of mononuclear cells capable of inducing maximal suppression and found that equal numbers of mononuclear and marrow cells were optimal. In the cocultures the cell density in the culture was kept constant at $5 \times 10^{5}$ cells/ plate. In all the experiments described, we have cocultured $2.5 \times 10^{5}$ bone marrow cells with $2.5 \times 10^{5}$ mononuclear cells. Plasma from the controls or FS in various doses, 0.05-0.5 ml, was also added to the normal bone marrow to test their suppressive and(or) enhancing capacity. We found no significant differences between the various plasma doses. Therefore, we used $0.1 \mathrm{ml}$ plasma in all the experiments described in the results section.

Statistical analysis was performed with Student's $t$ test.

\section{RESULTS}

In our initial experiments in which various concentrations of normal bone marrow cells were plated, there was no strict linear relationship between the number of CFU-C formed and the number of bone marrow cells plated. Marrows in doses of $5 \times 10^{5}, 2.5 \times 10^{5}$, and $1 \times 10^{5}$ formed $84 \pm 39($ mean \pm SD), $57 \pm 23$, and $17 \pm 5$ colonies, respectively. Blood mononuclear cells in a dose of $2.5 \times 10^{5}$ formed $3 \pm 3$ CFU-C.
Table II shows the CFU-C numbers and percentage of normals formed upon coculturing $2.5 \times 10^{5}$ normal bone marrow cells with equal numbers of blood mononuclear cells from FS and controls. When the blood neutrophil count of FS was below $1,000 / \mathrm{mm}^{3}$, there was significant suppression of CFU-C $(P<0.02)$. The three Felty's patients gave the following numbers of CFU-C and percentage of normals: $6,14 \% ; 19,31 \%$; and $28,39 \%$. No significant suppression of CFU-C occurred when blood mononuclear cells were obtained from the 10 normal controls, FS with neutrophil counts $>1,000 / \mathrm{mm}^{3}$, RA patients with normal neutrophil counts, or patients with malignancy and neutropenia (Table II).

Table III shows the cell type responsible for suppression. T-cell enriched preparations were the most efficient in inducing suppression $(P<0.01)$. Monocytes also contributed to the suppression of CFU-C $(P<0.05)$. Depletion of monocytes from the B-cell preparation abolished the suppressive ability of the Bcell preparation. The $\mathrm{T}$ - and B-cell preparations were $>91 \%$ and $>83 \%$ pure cell subpopulations, respectively. Contaminating cells in the $\mathrm{T}$ preparations were $<4 \%$ B cells and $<1 \%$ monocytes and in the B preparations were $12 \pm 4 \%$ monocytes and $<3 \%$ neutrophils. Plasma from the various FS patients at a dose of 0.1 $\mathrm{ml} /$ culture plate were not inhibitory to normal CFU-C (Table III). Increasing the plasma dose to $0.5 \mathrm{ml} /$ plate or decreasing the dose to $0.05 \mathrm{ml} / \mathrm{plate}$ did not significantly change the value of suppression (not shown in Table III).

Table IV shows the suppressor capacity of cells obtained from the various lymphoid compartments. It

TABLE II

Colony Forming Unit in Culture (CFU-C): Effects of Coculturing Normal Bone Marrow with Blood Mononuclear Cells from Patients with Felty's Syndrome or Controls

\begin{tabular}{lccccc}
\hline $\begin{array}{c}\text { Source of blood } \\
\text { mononuclear cells } \\
\text { (no. studied) }\end{array}$ & $\begin{array}{c}\text { No. } \\
\text { experiments }\end{array}$ & Neutrophil count & No. of CFU-C** & $\begin{array}{c}\text { Normal } \\
\text { (mean) }\end{array}$ & $P$ \\
\hline & & mean $\pm S D$ & mean $\pm S D$ S & $\%$ & \\
None (10) & 10 & - & $57 \pm 23$ & - & - \\
Normal (10) & 10 & $5,120 \pm 1,100$ & $63 \pm 17$ & - & - \\
Felty's (3) & 7 & $810 \pm 120$ & $18 \pm 11$ & 28 & 0.02 \\
Felty's (3) & 6 & $2,700 \pm 1,100$ & $42 \pm 14$ & 66 & NS** \\
RA" (6) & 9 & $4,200 \pm 1,750$ & $61 \pm 14$ & 97 & NS \\
Malignancy 9 (3) & 6 & $780 \pm 210$ & $50 \pm 25$ & 79 & NS \\
\hline
\end{tabular}

* See Methods for the number of cells cultured.

$\$$ See Methods for formula used for calculation.

$\$$ Mean \pm standard deviation of triplicate plates of all the experiments.

"Rheumatoid arthritis without neutropenia used as controls. Patients were on aspirin or $<7.5 \mathrm{mg}$ prednisone daily.

I Patients with solid tumors on chemotherapy and had neutropenia.

** Not significant. 
TABLE III

Blood Mononuclear Cell Type of Felty's Patient's Capable of Suppressing in Vitro Granulopoiesis of Normal Bone Marrow

\begin{tabular}{|c|c|c|c|}
\hline \multirow[b]{2}{*}{ Cell type } & \multicolumn{2}{|c|}{$\begin{array}{l}\text { No. of CFU-C formed } \\
\text { by normal bone } \\
\text { marrow* upon co- } \\
\text { culture with blood } \\
\text { cells from }\end{array}$} & \multirow[b]{2}{*}{ Suppression $\S$} \\
\hline & Normal & Felty's & \\
\hline & \multicolumn{2}{|c|}{ mean $\pm S D$} & $\%$ \\
\hline Unfractionated & $59 \pm 14$ & $18 \pm 11$ & 69 \\
\hline $\mathrm{T}^{\|}$ & $58 \pm 7$ & $13 \pm 3$ & 77 \\
\hline $\mathrm{B}^{\prime \prime}$ & $67 \pm 9$ & $41 \pm 11$ & 38 \\
\hline B minus monocytes" & $61 \pm 9$ & $58 \pm 7$ & 5 \\
\hline Plasma & $73 \pm 6$ & $71 \pm 8$ & 3 \\
\hline
\end{tabular}

* Normal bone marrow, in these experiments, when cultured alone gave $62 \pm 11$ CFU-C.

$\$$ Mean \pm standard deviation of triplicate cultures of six experiments performed on six allogeneic normal donors or three Felty's patients studied twice.

$\S$ See Methods for calculating percent suppression.

"See Methods for fractionation procedure and purity of cell type.

I $0.1 \mathrm{ml}$ was mixed with normal bone marrow before plating; no blood cells were added.

can be seen that except for normal splenic cells which induced mild suppression of normal allogeneic bone marrow CFU-C, both normal peripheral blood and bone marrow cells enhanced normal granulopoiesis and did not induce suppression. FS mononuclear cells from the three different organ sources were capable of suppressing normal bone marrow CFU-C; splenic $>$ bone marrow $>$ peripheral blood (Table IV, last column). It can also be seen from Table IV that the numbers of CFU-C formed upon culturing FS marrow by itself were few when compared to normals.

Table $\mathrm{V}$ shows the sequential studies of suppressor capacity of blood mononuclear cells of one FS patient before, and 3 and $21 \mathrm{wk}$ after splenectomy. It can be seen that $3 \mathrm{wk}$ after splenectomy the suppressive capacity of blood cells is no longer present. However, 21 wk postsplenectomy, there is evidence of suppression. The suppressive capacity roughly correlates with the absolute numbers of blood neutrophils.

\section{DISCUSSION}

The present study suggests that cells from patients with FS can suppress normal granulopoiesis in bone marrow cultures. These suppressor cells are predominantly $\mathrm{T}$ lymphocytes. Monocytes were also capable of inducing suppression. Splenic cells possess
TABLE IV

Comparative Study of Suppressor Capacity of Mononuclear Cells from Various Lymphoid Compartments on Colony Forming Units of Normal Bone Marrow

\begin{tabular}{|c|c|c|c|c|c|}
\hline \multicolumn{2}{|c|}{ Source of mononuclear cells } & \multicolumn{2}{|c|}{$\begin{array}{l}\text { No. of CFU-C formed } \\
\text { by the specified cell } \\
\text { type cultured }\end{array}$} & \multirow{2}{*}{$\begin{array}{c}\text { Per- } \\
\text { centage } \\
\text { of } \\
\text { normal } \\
\text { marrow } \\
\text { alone* }\end{array}$} & \multirow[b]{2}{*}{$\begin{array}{l}\text { Percentage } \\
\text { of normals }\end{array}$} \\
\hline \multirow[t]{2}{*}{ Donor } & $\begin{array}{l}\text { Organ (no. } \\
\text { studied) }\end{array}$ & Alone & $\begin{array}{l}\text { normal } \\
\text { marrow }\end{array}$ & & \\
\hline & & \multicolumn{2}{|c|}{ mean $\pm S D$} & $\%$ & $\%$ \\
\hline Normal & Marrow (16) & $57 \pm 23$ & $84 \pm 39$ & 147 & $97^{\prime \prime}$ \\
\hline Felty's & Marrow (2) & $2 \pm 1$ & $13 \pm 4$ & 23 & 15 I \\
\hline Normal & Blood (10) & $2 \pm 1$ & $60 \pm 20$ & 105 & $105^{\prime \prime}$ \\
\hline Felty's & Blood (3) & $1 \pm 1$ & $33 \pm 7$ & 58 & 55 đ \\
\hline Normal & Spleen $(1) \S$ & $9 \pm 2$ & $41 \pm 6$ & 72 & ND** \\
\hline Felty's & Spleen (1) & $1 \pm 1$ & $4 \pm 1$ & 7 & 109 \\
\hline
\end{tabular}

* No. of CFU-C formed upon (Coculturing $2.5 \times 10^{5}$ normal or FS cells with $2.5 \times 10^{5}$ normal bone marrow/Culturing $2.5 \times 10^{5}$ normal bone marrow alone) $\times 100$.

$\ddagger$ See Methods for the formula of calculation.

$\$$ After trauma splenectomy.

"Compared to normal cells from another normal donor cultured the same day at same cell density with the same specimen of normal marrow.

\ Compared to results of normal mononuclear cells of same type cocultured with the same normal allogeneic bone marrow.

** Not done. One normal spleen culture was studied.

the most potent suppressor capacity followed by those from bone marrow and peripheral blood. Mononuclear cells from normal donors, RA patients without splenomegaly or neutropenia, patients with malignancy and drug-induced neutropenia, and plasma from patients with FS or from normals failed to induce suppression.

TABLE V

Effects of Splenectomy in Felty's Syndrome on the Suppressive Capacity of Blood Mononuclear Cells

\begin{tabular}{lcrrc}
\hline $\begin{array}{c}\text { Time of test } \\
\text { in relation to } \\
\text { splenectomy }\end{array}$ & $\begin{array}{c}\text { No. of } \\
\text { experi- } \\
\text { ments* }\end{array}$ & $\begin{array}{c}\text { Total } \\
\text { leukocyte } \\
\text { count }\end{array}$ & $\begin{array}{c}\text { Absolute } \\
\text { neutrophil } \\
\text { count }\end{array}$ & $\begin{array}{c}\text { CFU-C, } \\
\text { percentage of } \\
\text { suppression } \$ \\
\text { (mean) }\end{array}$ \\
\hline \multicolumn{1}{c}{$w k$} & & & & $\%$ \\
Pre: 2 & 2 & 920 & 84 & 63 \\
Post: 3 & 2 & 12,150 & 7,400 & 0 \\
Post: 21 & 2 & 3,175 & 320 & 39 \\
\hline
\end{tabular}

* Two experiments performed the same week on one patient with FS.

$\ddagger$ Mean cell counts per cubic millimeter of the patient at time of the study.

\$ See Methods for calculating percentage of suppression. 
Previous studies of the mechanism of neutropenia in FS have been contradictory (3-7) and focused on humoral factors, primarily antibodies to leukocytes. Recently, there has been increasing evidence that $\mathrm{T}$ cells play a role in RA. An increased number of $\mathrm{T}$ lymphocytes in synovial fluid (19) and synovial tissue (20) of patients with RA and in the peripheral blood of patients with FS (21) has been described. Moreover, bone marrow studies in FS patients have demonstrated hyperplasia of lymphoid and monocytoid mononuclear cells (22). Removal of $\mathrm{T}$ lymphocytes from patients with rheumatoid arthritis by thoracic duct drainage has been shown to decrease disease activity (23).

Our results support those of others $(3,7,8)$ in which decreased granulopoiesis in vitro in FS was shown. Our results show this suppression to be by a cellular and not by a serum mechanism. Our results do not exclude the possibility that neutropenia may be due, in some cases, to IgG bound to mature neutrophils as has recently been demonstrated by Logue (5). The factors inducing the suppressor cell activity in FS and the mechanism by which suppression of granulopoiesis is mediated are unknown at the present time. Small molecular weight-soluble factors produced by $\mathrm{T}$ cells which are capable of inducing suppression in vitro have been described in other systems (24). We doubt that the in vitro suppression of granulopoiesis demonstrated in our study is due to alloimmunization since suppression was shown by cells from one patient who was nulliparous and did not receive transfusions. The target of suppressor cells was not identified in this study since our CFU-C assay was done in the absence of added colony-stimulating factor or feeder layers. The suppressor activity might be directed at the cells which release colony-stimulating factor or at the myeloid precursor cells, thus preventing in vitro differentiation into mature granulocytes.

The suppressor effect of the spleen has been shown in the single patient who had a splenectomy. Splenectomy in FS has a temporary beneficial effect on neutrophil counts which may be due to removal of the bulk of suppressor cells. In mice $(25,26)$ and man (27) the spleen has been shown to be the principal organ in which suppressor cells reside. In man bone marrow $\mathrm{T}$ cells were shown by us to have greater suppressor activity than blood T cells $(18,28)$. The recurrence of neutropenia several weeks after splenectomy may be due to activation of suppressor cells present in other organs such as bone marrow. Our findings therefore, may offer an explanation for the transient beneficial effects of splenectomy $(29,30)$. It is apparent that other therapeutic modalities aimed at modulating the hyperactive suppressor cells are needed. The administration of antithymocyte globulin to a patient who suffered from aplastic anemia due to hyperactive suppressor $\mathrm{T}$ cells was effective in the partial correction of pancytopenia (28). More work is needed to characterize the surface markers of suppressor cells, the mechanism by which they mediate suppression and the factor(s) that are responsible for the suppressor cell activation in vivo. The possibility that activation of suppressor cells may follow and not precede neutropenia should also be carefully considered.

\section{ACKNOWLEDGMENTS}

The authors would like to thank Mrs. Maria G. Robinson and Miss Barbara Sooley for excellent technical assistance.

This work was supported by Institutional Research Funds of the Universities of Missouri and Kansas, and by a Veterans Administration research grant.

\section{REFERENCES}

1. Felty, A. R. 1924. Chronic arthritis in the adult, associated with splenomegaly and leukopenia. Bull. Johns Hopkins Hosp. 35: 16-20.

2. Hirschboeck, J. S. 1946. Hematologic effects of splenectomy in Still-Chauffard-Felty syndrome. Blood. 1: $247-255$

3. Vincent, P. C., J. A. Levi, and A. MacQueen. 1974. The mechanism of neutropenia in Felty's syndrome. $\mathrm{Br}$. J. Haematol. 27: 463-475.

4. Rosenthal, F. D., J. M. Beeley, K. Gelothorpe, and R. W. Doughty. 1974. White-cell antibodies and the aetiology of Felty's syndrome. Q.J. Med. 43: 187-203.

5. Logue, G. 1976. Felty's syndrome: granulocyte-bound immunoglobulinemia and splenectomy. Ann. Intern. Med. 85: 437-442.

6. Hutchison, M. E., and W. D. Alexander. 1954. Splenic neutropenia in the Felty's syndrome. Blood. 9: 986-998.

7. Duckham, D. J., R. L. Rhyne, Jr., F. E. Smith, and R. C. Williams, Jr. 1975. Retardation of colony growth of in vitro bone marrow culture using sera from patients with Felty's syndrome, disseminated lupus erythematosus (SLE), rheumatoid arthritis, and other disease states. Arthritis Rheum. 18: 323-333.

8. Gupta, R. C., W. A. Robinson, and D. Albrecht. 1975. Granulopoietic activity in Felty's syndrome. Ann. Rheum. Dis. 34: 156-161.

9. Miller, J. F. A. P. 1975. T cell regulation of immune responsiveness. Ann. N. Y. Acad. Sci. 249: 9-26.

10. Gershon, R. K. 1975. A disquisition on suppressor $T$ cells. Transplant. Rev. 26: 170-185.

11. Waldman, T. A., S. Broder, R. M. Blease, M. Durm, M. Blackman, and W. Strober. 1974. Role of suppressor $\mathrm{T}$ cells in pathogenesis of common variable hypogammaglobulinemia. Lancet. II: 609-613.

12. Broder, S., R. Humphrey, M. Durm, M. Blackman, B. Meade, C. Goldman, W. Strober, and T. Waldmann. 1975. Impaired synthesis of polyclonal (non-paraprotein) immunoglobulins by circulating lymphocytes from patients with multiple myeloma. Role of suppressor cells. N. Engl. J. Med. 293: 887-892.

13. Ascensāo, J., R. Pahwa, and W. Kagan. 1976. Aplastic anemia, evidence for an immunological mechanism. Lancet. I: $669-670$.

14. Hoffman, R., E. D. Zanjani, J. Vila, R. Zalusky, J. D Lutton, and L. R. Wasserman. 1976. Diamond-Blackfan 
syndrome: lymphocyte-mediated suppression of erythropoiesis. Science (Wash. D. C.). 193: 899-900.

15. Stobo, J. D., S. Paul, R. E. Van Scoy, and P. E. Hermans. 1976. Suppressor thymus-derived lymphocytes in fungal infection. J. Clin. Invest. 57: 319-328.

16. Abdou, N. I., A. Sagawa, E. Pascual, J. Hebert, and S. Sadeghee. 1976. Suppressor T-cell abnormality in idiopathic systemic lupus erythematosus. Clin. Immunol. Immunopathol. 6: 192-199.

17. Abdou, N. I., R. P. Lisak, B. Zweiman, I. Abrahamsohn, and A. S. Penn. 1974. The thymus in myasthenia gravis. Evidence for altered cell populations. N. Engl. J. Med. 291: $1271-1275$.

18. Abdou, N. L., J. Alavi, and N. I. Abdou. 1976. Human bone marrow lymphocytes: $B$ and $T$ cell precursors and subpopulations. Blood. 47: 423-430.

19. Dorwart, B. B., J. Hebert, H. R. Schumacher, and N. I. Abdou. 1975. Cellular and humoral immune parameters of synovial fluid and blood in rheumatoid arthritis. $J$. Rheumatol. 2: 363-372.

20. Van Boxel, J. A., and S. A. Paget. 1975. Predominantly T cell infiltrate in rheumatoid synovial membranes. N. Engl. J. Med. 293: 517-520.

21. Williams, R. C., Jr., J. R. DeBoard, O. J. Mellbye, R. P. Messner, and F. D. Lindström. 1973. Studies of $\mathrm{T}$ - and B-lymphocytes in patients with connective tissue diseases. J. Clin. Invest. 52: 283-295.

22. Williams, R. C. 1974. Rheumatoid arthritis as a systemic disease. In Major Problems in Internal Medicine. R. C. Williams, editor. W. B. Saunders Co., Philadelphia. 4: $71-84$.
23. Wegelius, O., V. Laine, and B. Lindstrom. 1970. Fistula of the thoracic duct as immunosuppressive treatment in rheumatoid arthritis. Acta Med. Scand. 187: 539-544.

24. Rich, R. R., and C. W. Pierce. 1974. Biological expressions of lymphocyte activation. III. Suppression of plaque-forming cell responses in vitro by supernatant fluids from concanavalin A-activated spleen cell cultures. J. Immunol. 112: 1360-1365.

25. Herzenberg, L. A., E. L. Chan, M. M. Ravitch, R. J Riblet, and L. A. Herzenberg. 1973. Active suppression of immunoglobulin allotype synthesis. III. Identification of $T$ cells as responsible for suppression by cells from spleen, thymus, lymph node, and bone marrow. J. Exp. Med. 137: 1311-1324.

26. Rich, R. R., and S. S. Rich. 1976. Suppression of mixed lymphocyte reactions by alloantigen-activated spleenlocalizing thymocytes. Cell. Immunol. 22: 358-368.

27. Sampson, D., C. Grotelueschen, and H. M. Kauffman. 1975. The human splenic suppressor cell. Transplantation (Baltimore). 20: 362-367.

28. Amare, M., N. L. Abdou, J. D. Cook, and N. I. Abdou. 1977. Aplastic anemia associated with bone marrow suppressor T-cell hyperactivity. Successful treatment with antithymocyte globulin. Clin. Res. 25: 353. (Abstr.)

29. Moore, R. A., C. M. Brunner, W. R. Sandusky, and B. S. Leavell. 1971. Felty's syndrome: Long-term followup after splenectomy. Ann. Intern. Med. 75: 381-385.

30. Barnes, C. G., A. L. Turnbull, and B. Vernon-Roberts 1971. Felty's syndrome: A clinical and pathological survey of 21 patients and their response to treatment. Ann. Rheum. Dis. 30: 359-374. 